\title{
Is Helicobacter pylori associated hypergastrinaemia due to the bacterium's urease activity or the antral gastritis?
}

\author{
R S Chittajallu, C A Dorrian, W D Neithercut, S Dahill, K E L McColl
}

University Department of Medicine and

Therapeutics

R S Chittajallu

K E L McColl

University Department

of Pathological

Biochemistry

C A Dorrian

W D Neithercut

University Department of Pathology, Western Infirmary, Glasgow

S Dahill

Dr Kenneth E L McColl,

Medicine and Therapeutics,

Gardiner Institute, Western

Infirmary, Glasgow G11 6NT.

Accepted for publication

28 January 1991
Correspondence to:

University Department of

\begin{abstract}
Eradication of Helicobacter pylori is associated with a fall in serum gastrin but the way in which the infection raises the serum gastrin concentration is not clear. It may be related to the ammonia produced by the bacterium's urease stimulating gastrin release by the antral G cells. Alternatively, the antral gastritis induced by the infection may modify the regulation of gastrin release. We have examined serum gastrin in 10 patients before and 24 hours after starting triple anti-H pylori treatment consisting of tripotassium dicitrato bismuthate $120 \mathrm{mg}$ four times daily, metronidazole $\mathbf{4 0 0} \mathrm{mg}$ three times daily, and amoxycillin $500 \mathrm{mg}$ three times daily. The urease activity, assessed by the 20 minute value of the 14C-urea breath test, fell from a median of 176 (range 116-504) $\mathrm{kg} \%$ dose $/ \mathrm{mmol} \mathrm{CO}_{2} \times 100$ pretreatment to $5(2-15)$ at 24 hours $(p<0.005)$. The median antral gastritis score was $6(4-6)$ pretreatment and fell to $3(2-5)$ at 24 hours $(p<0.02)$, and this was due to resolution of the polymorphonuclear component. Despite this complete suppression of bacterial urease activity and partial resolution of antral gastritis the median basal gastrin concentration remained unchanged, being $57 \mathrm{ng} / \mathrm{l}$ (45-77) pretreatment and $59 \mathrm{ng} / \mathrm{l}(45-80)$ at 24 hours
\end{abstract}

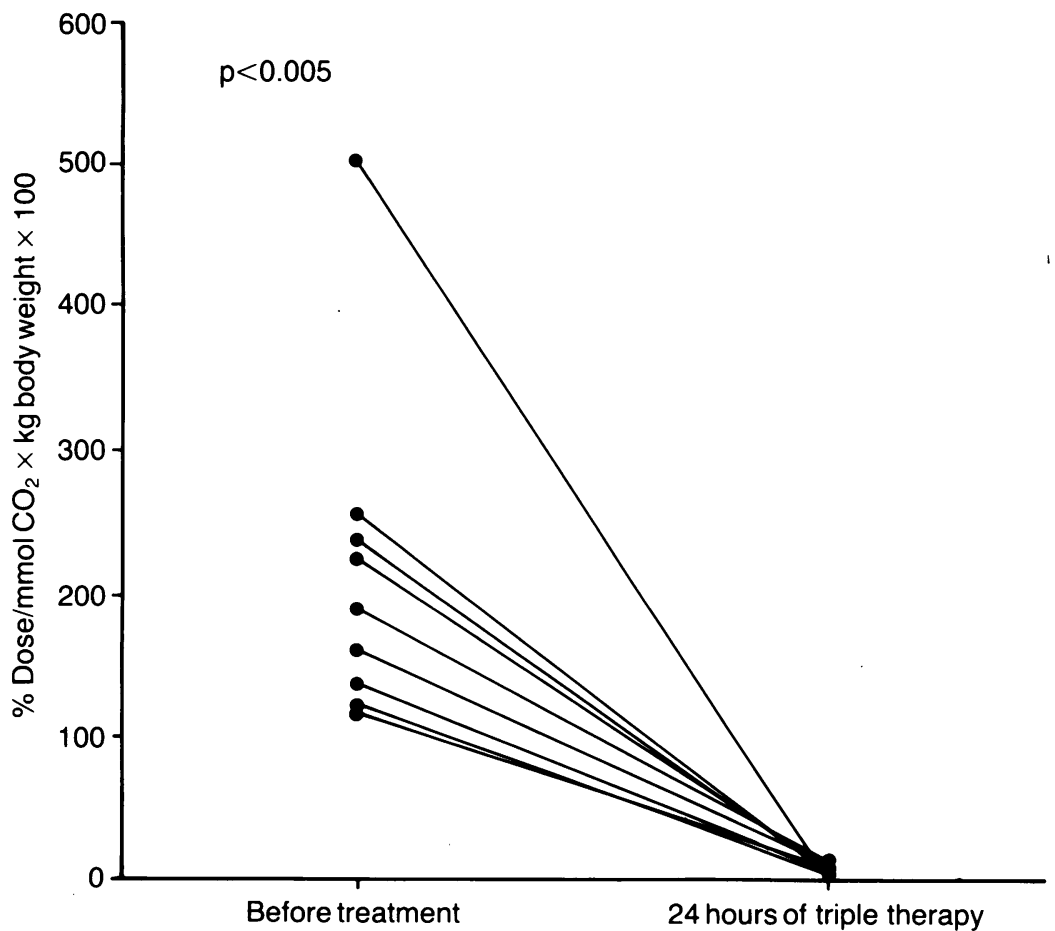

Figure 1: Breath test 20 minute value before and 24 hours after start of triple therapy in 10 patients. and the median integrated gastrin response to a standardised meal was also unaltered, being $4265 \mathrm{ng} / \mathrm{l} / \mathrm{min}$ (range 1975-8350) and $4272 \mathrm{ng} / \mathrm{l}$ min (range 2075-6495) respectively. These findings do not support a causal association between $\boldsymbol{H}$ pylori urease activity and hypergastrinaemia and show rapid improvement of antral gastritis after starting anti- $H$ pylori treatment.

There is now convincing evidence that Helicobacter pylori infection plays an important part in the pathogenesis of duodenal ulcer disease. The way in which the chronic antral infection predisposes to duodenal ulceration is unclear but stimulation of excessive gastrin release may be important. ${ }^{1-4}$ Eradication of $H$ pylori infection results in a fall in the basal gastrin concentration of $27-33 \%$ and a fall of $30-58 \%$ in the integrated gastrin response to a meal. ${ }^{5}$ The mechanism by which $H$ pylori infection raises plasma gastrin concentration is unclear.

The hypergastrinaemia might be related to the organism's high urease activity. The production of ammonia at the antral epithelial surface could raise the local $\mathrm{pH}$, resulting in loss of the physiological inhibition of gastrin release by intragastric acid. ${ }^{67}$ The ammonia might also increase gastrin release by directly stimulating the $\mathrm{G}$ cells as has been shown to occur in rats. ${ }^{8} \mathrm{~A}$ second explanation for the hypergastrinaemia is that it might be due to the chronic inflammation which $H$ pylori induces in the underlying antral mucosa and which resolves on eradication of the infection. Wyatt et al have shown that antral gastritis, irrespective of $H$ pylori status, is associated with raised plasma gastrin concentration. ${ }^{9}$ In addition the $T$ lymphocyte products, interleukin- 2 and gamma interferon, have been shown to stimulate gastrin release in studies on isolated perfused canine antrum. ${ }^{10}$

In an attempt to differentiate between the effects of the $H$ pylori urease activity and the antral gastritis we decided to examine serum gastrin concentrations soon after starting $H$ pylori eradication treatment. At this early time we hoped to achieve complete suppression of bacterial urease activity without appreciable resolution of the antral gastritis.

\section{Patients}

Ten patients (seven men, age range $31-65$ years) with a history of endoscopically confirmed duodenal ulcer were studied. In each $H$ pylori infection had been shown by histology of antral biopsy specimen and rapid urease test (CLO 
(A)

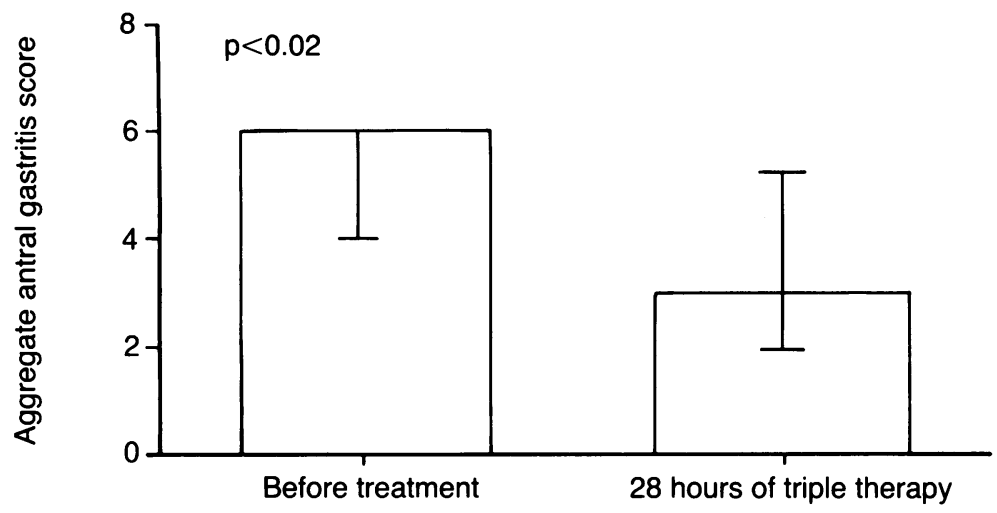

(B)

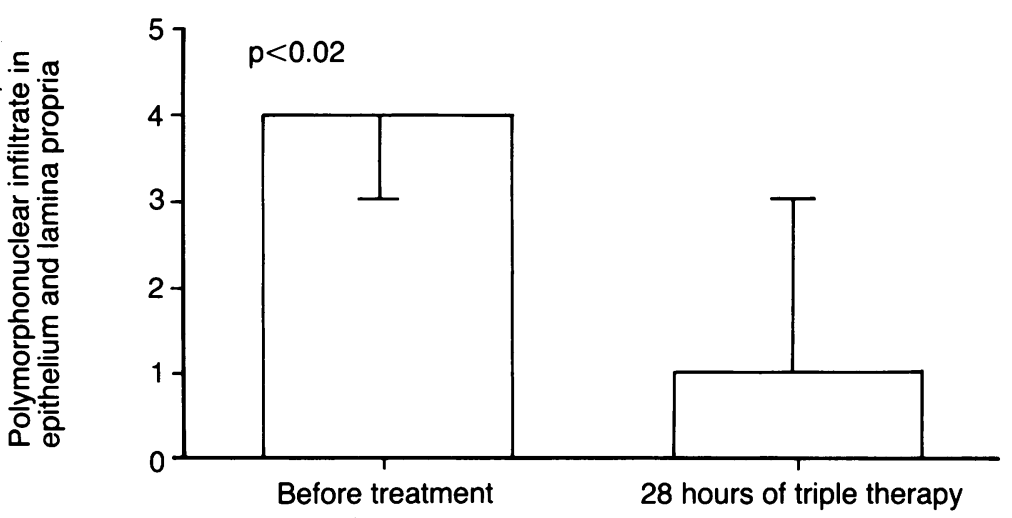

(C)

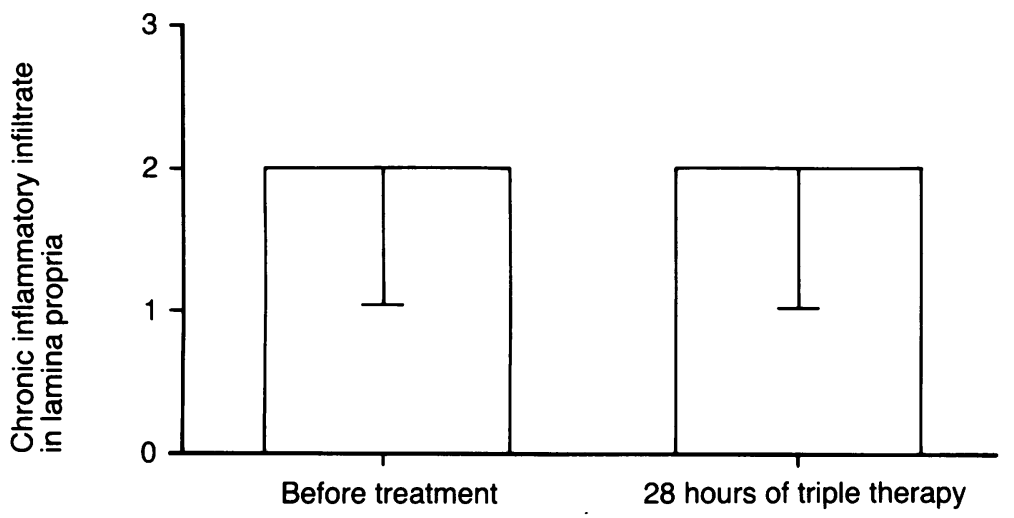

Figure 2: Change in antral gastritis 28 hours after start of triple therapy. The columns represent the median value for eight patients and the error bars the range.

test)." All the patients discontinued any treatment with acid inhibitory agents for at least two weeks before entering the study. During this period they were allowed antacids except for the 24 hours preceding the first study day. None had taken bismuth preparations previously.

Four volunteers who were shown to be negative for $H$ pylori by a $14 \mathrm{C}$-urea breath test served as a control group.

\section{Methods}

In eight of the patients the following studies were conducted. After a 14C-urea breath test to determine $H$ pylori urease activity, upper gastointestinal endoscopy was performed and two antral biopsy specimens taken for assessment of severity of antral gastritis. Within three weeks of this the patients reported fasted one morning and two samples of venous blood were collected 15 minutes apart for estimation of basal serum gastrin concentration. They then drank over five minutes $250 \mathrm{ml}$ of Ensure Plus (Abbott Laboratories, UK) which contains $12.5 \mathrm{~g}$ fat, $15.6 \mathrm{~g}$ protein, and $50 \mathrm{~g}$ carbohydrate. The gastrin response to this was measured by taking serum samples five minutes after completing the drink and then at 10 minute intervals for 90 minutes.

On the morning after completing the above tests they started taking tripotassium dicitrato bismuthate (De-Nol) $120 \mathrm{mg}$ four times daily, amoxycillin $500 \mathrm{mg}$ three times daily, and metronidazole $400 \mathrm{mg}$ three times daily (triple therapy). They took one complete day's treatment and reported fasted the following morning. Their morning dose was administered at 0800 and one hour later two samples of blood were obtained 15 minutes apart for estimation of basal serum gastrin concentration. Immediately after this a 14C-urea breath test was performed. The breath test requires drinking $250 \mathrm{ml}$ of Ensure Plus to delay gastric emptying of the $14 \mathrm{C}$ urea. It was therefore possible simultaneously to reassess the gastrin response to this. Studies have shown that a fall in meal stimulated gastrin response after eradication of $H$ pylori occurs with various meals $^{312}$ and is not specific to the Oxo meal. At 1300 hours an upper gastrointestinal endoscopy was repeated and further antral biopsy specimens obtained for a CLO test and to reassess the severity of the gastritis. The four hour delay between the breath test and endoscopy was to allow gastric emptying of the Ensure Plus. The patients then went on to complete the three week course of triple therapy. One month after completion of therapy their $H$ pylori status was reassessed by $14 \mathrm{C}$-urea breath test, antral histology, and CLO test.

The other two patients were studied in a similar fashion except that their gastrin response to a standardised Oxo meal (Oxo, Croydon, UK) was assessed immediately before performing the 14C-urea breath test. This prolonged the second study day and meant that upper gastrointestinal endoscopy could not be performed. The response to the Oxo meal was undertaken as our original observation of a pronounced fall in integrated gastrin response after eradication of $H$ pylori had used this meal. ${ }^{5}$ The standardised Oxo meal was prepared by dissolving two Oxo cubes in $200 \mathrm{ml}$ of water at $50^{\circ} \mathrm{C}$. They drank this over five minutes. The first sample of serum for gastrin estimation was collected five minutes after completion of the meal and further samples at 10 minute intervals for 90 minutes.

The four healthy volunteers without $H$ pylori infection served as the control group. They had their gastrin response to a standardised Oxo meal measured before and 24 hours after starting the same triple therapy regimen as the patient group. 


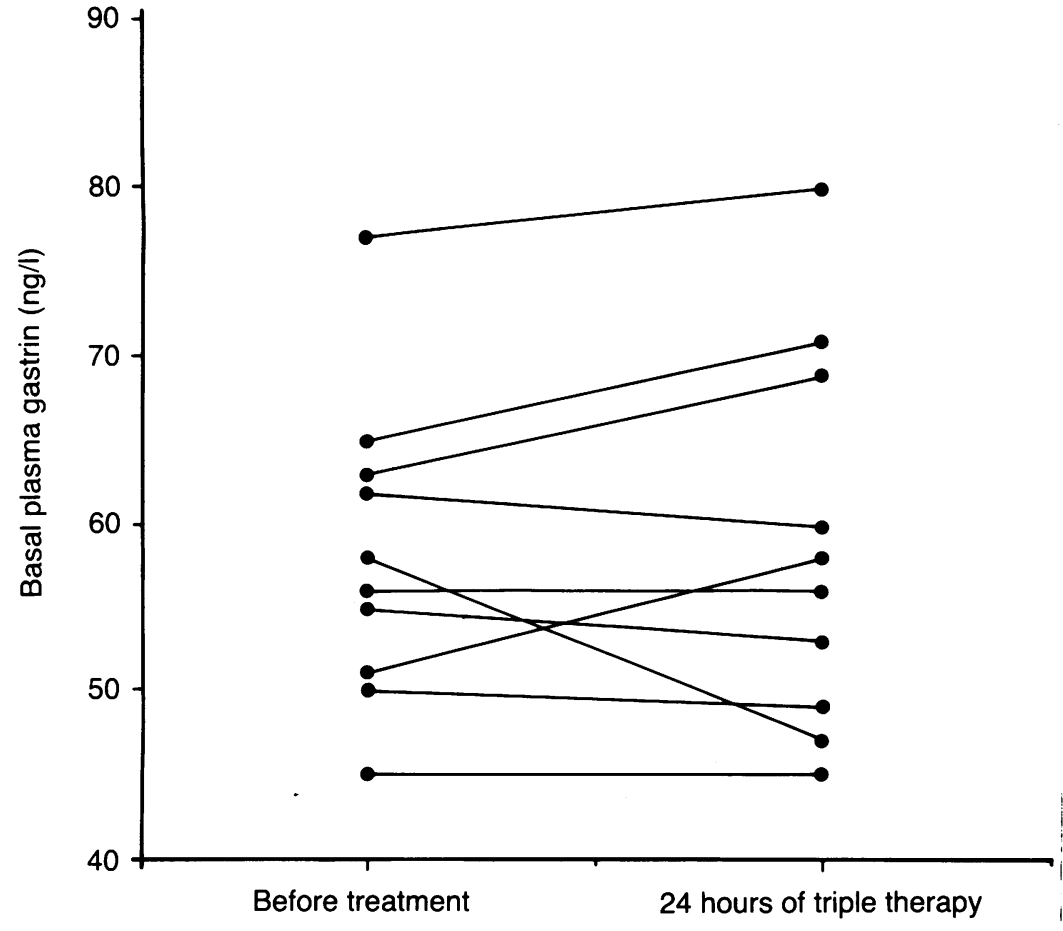

Figure 3: Basal plasma gastrin before and 24 hours after start of triple therapy in 10 patients.

were collected in plain containers and after clotting centrifuged at $3000 \mathrm{~g}$ for 10 minutes at $4^{\circ} \mathrm{C}$ and the serum stored at $-20^{\circ} \mathrm{C}$.

Serum gastrin was measured using commercial radioimmunoassay kits obtained from CIS (UK). The gastrin assay reacted $100 \%$ with gastrin-17 and $72 \%$ with gastrin-34 in molar terms. The minimum detection limit of the assay was $20 \mathrm{ng} / 1$ (coefficient of variation $=22 \%$ ) and the interassay coefficient of variation was $<10 \%$ from $40-700 \mathrm{ng} / \mathrm{l}$. All samples for each patient were measured in the same assay.

For the 14C-urea breath tests the patients drank $250 \mathrm{ml}$ of Ensure Plus immediately followed by $0.4 \mathrm{MBq}$ 14C-urea (Amersham International) in $25 \mathrm{ml}$ of water. Breath samples

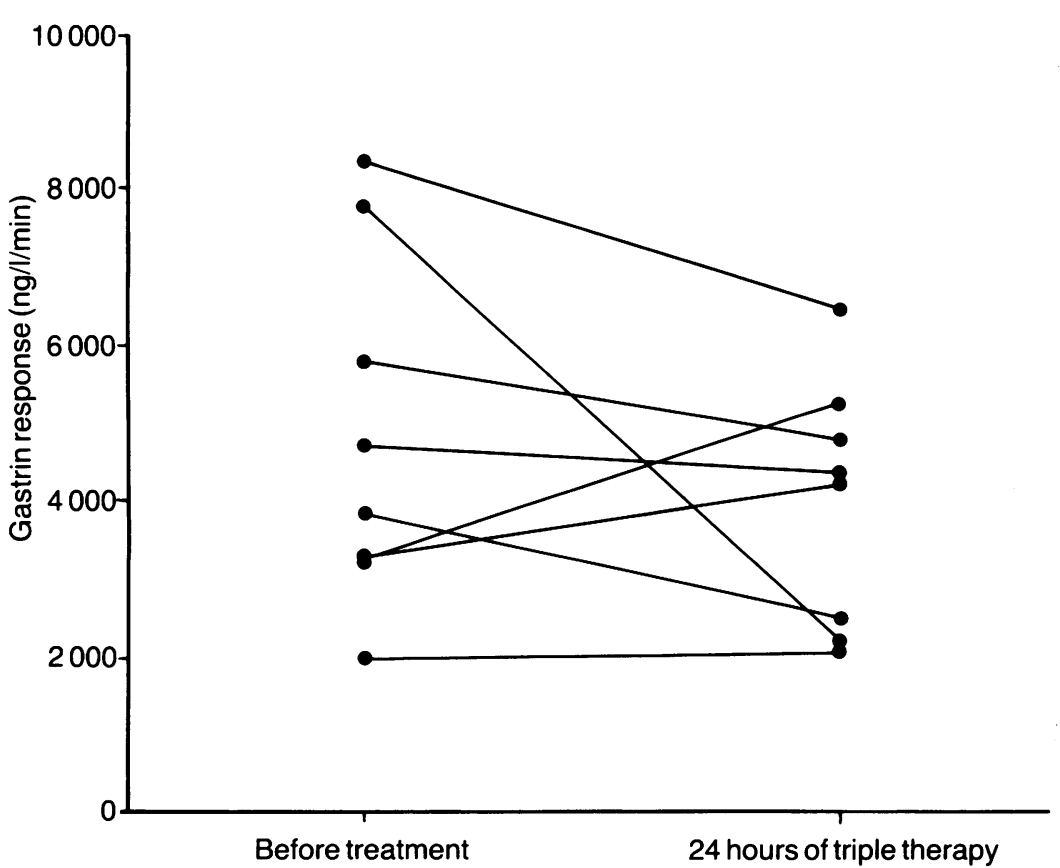

Figure 4: Integrated gastrin response to Ensure Plus before and 24 hours after start of triple therapy in eight patients. were collected every 10 minutes for 30 minutes and analysed as described by Marshall and Surveyor. ${ }^{13}$ The 20 minute value was used as the determinant of the urease activity. ${ }^{14}$

The antral biopsy specimens were stained with haematoxylin and eosin and examined double blind by one pathologist and given an aggregate gastritis score of between 1 and 10 as described by Rauws et al. ${ }^{15}$ Chronic inflammatory infiltrate in the lamina propria was scored as $0-2$, lamina propria polymorph infiltrate $0-3$, intraepithelial polymorph infiltrate $0-3$, and mucosal erosions as $0-2$.

Statistical significance was assessed by Wilcoxon signed rank sum test. The study was approved by the Western Infirmary Ethical Committee and each patient gave informed written consent.

\section{Results}

The 24 hours of triple therapy produced profound suppression of $H$ pylori urease activity. The breath test 20 minute reading (\%14C dose per mmol $\mathrm{CO}_{2} \times 100 \times \mathrm{kg}$ body weight) fell from a median pretreatment value of 176 (range 116$504)$ to 5 (range $2-15)(\mathrm{p}<0.005)$ (Fig 1). The CLO test, which was positive at five hours in all patients before treatment, was negative at $>24$ hours when repeated 28 hours after starting the triple therapy. There was also evidence of some resolution of the gastritis within this period. The median pretreatment aggregate antral gastritis score in the eight patients studied was 6 (range 4-6) compared with 3 (range 2-5) after 28 hours' therapy $(\mathrm{p}<0.02)$ (Fig 2A). The change was mainly in the polymorph infiltrate in the epithelium and lamina propria with little change in the chronic inflammatory infiltrate in the lamina propria. The sum of the scores of the polymorph infiltrate in the epithelium and the lamina propria fell from a median pretreatment value of 4 (range 3-4) to 1 (range 1-3) after 28 hours' therapy $(p<0.02)$ (Fig 2B). The score of the chronic inflammatory infiltrate in the lamina propria remained unchanged at 2 (range 1-2) (Fig 2C).

Despite profound suppression of urease activity and significant reduction in the severity of the polymorphonuclear infiltrate in the antral mucosa neither the basal nor the meal stimulated serum gastrin concentrations were altered. The median pretreatment basal gastrin concentration in the 10 patients was $57 \mathrm{ng} / \mathrm{l}$ (range 45-77) compared with $59 \mathrm{ng} / \mathrm{l}$ (range 45-80) after 24 hours of triple therapy (Fig 3). The median pretreatment integrated gastrin response to the Ensure Plus meal in the eight patients was 4265 $\mathrm{ng} / \mathrm{l} / \mathrm{min}$ (range 1975-8350) and after 24 hours of triple therapy $4272 \mathrm{ng} / \mathrm{l} / \mathrm{min}$ (range 2075-6495) (Fig 4).

The integrated gastrin response to the Oxo meal was also unchanged in the two patients studied, their pretreatment values being 5455 and $1760 \mathrm{ng} / \mathrm{l} / \mathrm{min}$ and after 24 hours' triple therapy 5070 and $1595 \mathrm{ng} / \mathrm{l} / \mathrm{min}$, respectively (Fig 5).

Of the 10 patients, $H$ pylori was eradicated in six when reassessed one month after completion of triple therapy. 
$\rightarrow$ Before treatment $-\cdots-24$ hours of triple therapy

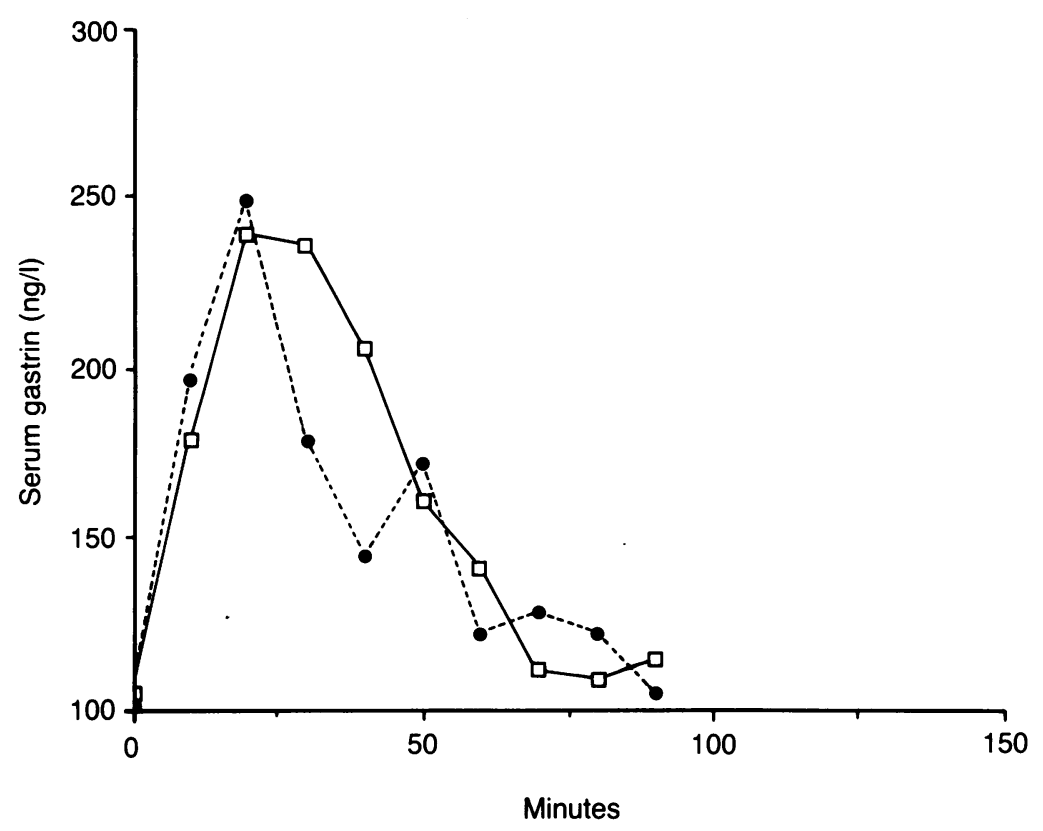

Figure 5: Representative gastrin response to Oxo meal before and 24 hours after start of triple therapy. The meal was started at time 0.

In the four healthy volunteers without $H$ pylori infection there was no change in the integrated gastrin response to an Oxo meal after 24 hours of triple therapy. Their mean pretreatment value was $4500 \mathrm{ng} / \mathrm{l} / \mathrm{min}$ (range $2000-6000$ ) and after 24 hours' therapy $3760 \mathrm{ng} / \mathrm{l} / \mathrm{min}$ (range 2000$6500)$.

\section{Discussion}

Helicobacter pylori has high urease activity by which it hydrolyses urea to produce ammonia and carbon dioxide. ${ }^{16}$ It has been postulated that the hypergastrinaemia associated with chronic $H$ pylori infection is secondary to the production of ammonia by the organism close to the antral epithelial cell surface. ${ }^{17}$ This could directly stimulate gastrin release by the antral $\mathrm{G}$ cells or act indirectly by raising antral surface $\mathrm{pH}$ and thus prevent physiological suppression of gastrin release by gastric acid. In this study the triple therapy produced complete suppression of the bacterial urease activity. This is not surprising as bismuth has been shown to be a powerful inhibitor of $H$ pylori urease activity as well as being bactericidal. ${ }^{18}$ Our observation that this degree of suppression of $H$ pylori urease activity has not resulted in a fall in basal serum gastrin or meal stimulated gastrin response does not support the hypergastrinaemia being directly related to the bacterial urease activity. If the hypergastrinaemia were due to a rise in antral surface $\mathrm{pH}$ by bacterial ammonia, the hormone level should fall rapidly after suppression of ammonia production and thereby fall in antral surface $\mathrm{pH}$. In patients with grossly raised gastrin concentrations due to achlorhydria, intragastric instillation of hydrochloric acid causes the plasma gastrin to fall within 5-15 minutes. ${ }^{19}$
The possibility must be considered that the antibacterial treatment could have independently stimulated gastrin release and thus obscured a fall in gastrin due to its suppression of urease activity. The absence of any rise in gastrin after 24 hour triple therapy in the $H$ pylorinegative control subjects excludes this, however.

Our findings in this study are consistent with those of our earlier study in which we observed that inhibiting $H$ pylori urease activity with acetohydroxamic acid did not lower the serum gastrin concentration in duodenal ulcer patients. ${ }^{20}$ In the study with acetohydroxamic acid we achieved only partial suppression of urease activity (median 20 minute value of the 14C-urea breath test 22, range 14-95) and there was the possibility that the suppression of ammonia production may have been inadequate to produce a fall in serum gastrin. In the present study, with 24 hours' triple therapy the urease activity, as assessed by the 14C-urea breath test, was suppressed to a median value of 5 (range 2-15) which was similar to the value 2 (range $0-5$ ) previously observed in patients one month after eradication. ${ }^{5}$ The lack of an association between $H$ pylori urease activity and serum gastrin in these studies is also consistent with our previous observation that increasing $H$ pylori ammonia production by administering urea did not raise gastrin in duodenal ulcer subjects. ${ }^{+}$

It is now necessary to consider alternative explanations for the hypergastrinaemia. It is possible that it is related to the effects on the antral $G$ cells of the chronic inflammation that $H$ pylori infection induces in the antral mucosa. Twenty eight hours after the start of anti- $H$ pylori treatment there was already early resolution of the antral gastritis but no change in the gastrin concentration. The change in the gastritis score, however, only affected the degree of infiltration of the epithelium and lamina propria with polymorphonuclear cells and there was no change in the chronic inflammatory infiltrate. It has been shown in isolated perfused canine antrum that the $T$ lymphocyte products, interleukin- 2 and gamma interferon, stimulate gastrin release.$^{10} \mathrm{It}$ is possible that resolution of the chronic inflammatory infiltrate is required before a change in the plasma gastrin concentration can be observed.

A third explanation for the hypergastrinaemia is that it is a compensatory response to inhibition of parietal cell function by $H$ pylori. The organism has been shown to inhibit parietal cells in vitro ${ }^{21}$ and acute $H$ pylori infection may result in profound hypochlorhydria in humans. ${ }^{22}$ Some inhibition of parietal cell function may persist during chronic infection producing a compensatory increase in gastrin release.

Urease has been proposed as being essential for the survival of $H$ pylori in the low $\mathrm{pH}$ environment of the stomach. ${ }^{23}$ By making ammonia the organism is thought to make the $\mathrm{pH}$ of its environment more favourable to its survival. Despite total suppression of urease activity in all our patients with triple therapy, eradication was achieved in only four. This indicates that urease activity is not essential for the organism's survival once the infection is established within the gastric mucous layer. It does not, however, exclude the possibility that 
the organism's ammonia production protects it from gastric acid when the infection is first being contracted.

This study indicates that the hypergastrinaemia in patients with $H$ pylori infection is not directly linked to the bacterial urease activity and ammonia production. It also highlights the rapid rate of resolution of the acute inflammatory cell component of the antral gastritis following commencement of anti- $H$ pylori treatment.

1 Oderda G, Vaira D, Holton J, Ainley C, Altare F, Ansaldi N. Amoxycillin and tinidazole for Campylobacter pylori gastritis in children: assessment by serum IgG antibody, gastritis in children: assessment by serum IgG antiboc
pepsinogen I and gastrin levels. L ancet 1989; i: 690-2.

2 Levi S, Beardshall K, Swift I, Foulkes W, Playford R, Ghosh $P$, et al. Antral Helicobacter pylori, hypergastrinaemia and duodenal ulcers: effect of eradicating the organism. $B M \mathcal{F}$ 1989; 299: 1504-5.

3 Graham DY, Opekun A, Lew GM, Evans DJ, Klein PD, Evans DG. Ablation of exaggerated meal stimulated gastrin release in duodenal ulcer patients after clearance of Helicobacter pylori infection. Am 7 Gastroenterol 1990; 85: 394-8.

4 Chittajallu RS, Neithercut WD, MacDonald AMI, McColl KEL. Effect of increasing Helicobacter pylori ammonia KEL. Effect of increasing Helicobacter pylori ammonia production by urea infusion
tions. Gut $1991 ; 32: 21-4$.

5 McColl KEL, Fullarton GM, Nujumi AM, MacDonald AM, Brown IL, Hilditch TE. Lowered gastrin and gastric acidity after eradication of Campylobacter pylori in duodenal ulcer. Lancet 1989; ii: 499-500.

6 Walsh JH, Richardson CT, Fordtran JS. pH dependence of acid secretion and gastrin release in normal and ulcer subjects. $\mathcal{F}$ Clin Invest 1975; 55: 462-8.

7 Lichtenberger LM, Nelson AA, Graziani LA. Amine trapping: physical explanation for the inhibitory effect of gastric acidity on the postprandial release of gastrin. Gastroenterology 1986; 90: 1223-31.

8 Lichtenberger LM, Graziani LA, Dubinsky WD. Importance of dietary amines in meal induced gastrin release. $A m \mathcal{F}$ Physiol 1982; 243: G341-7.
9 Wyatt JI, Rathbone BJ, Green DM, Primrose J. Raised fasting serum gastrin in chronic gastritis is independent of Campylobacter pylori status and duodenal ulceration. Gut 1989; 30: A1483.

10 Teichmann RK, Pratschke E, Grab J, Hammer C, Brendel W. Gastrin release by interleukin-2 and gamma-interferon in vitro. Can f Physiol Pharmacol 1986; 64 (suppl): 62 .

11 Marshall BJ, et al. Rapid urease test in the management of Campylobacter pyloridis-associated gastritis. Am $\mathcal{F}$ Gastroenterol 1987; 82: 200-10.

12 Levi S, Beardshall K, Swift I, Foulkes W, Playford R, Ghosh $\mathrm{P}$, et al. Antral Helicobacter pylori, hypergastrinaemia and duodenal ulcers: effect of eradicating the organism. $B M \mathcal{F}$ 1989; 299: 1504-5.

13 Marshall BJ, Surveyor I. Carbon-14 urea breath test for the diagnosis of Campylobacter pylori associated gastritis. f Nucl Med 1988; 29: 11-6.

14 Bell GD, Weil J, Harrison G, Morden A, Jones PH, Grant $\mathrm{PW}$, et al. 14C-urea breath analysis, a non-invasive test for Campylobacter pylori in the stomach [Letter]. Lancet 1987 i: $1367-8$.

15 Rauws EAJ, Langenberg W, Houthoff HJ, Zanen HC, Tytgat GNJ. Campylobacter pyloridis - associated chronic acute antral gastritis. Gastroenterology 1988; 94: 33-40.

6 Marshall B, Langton S. Urea hydrolysis in patients with Campylobacter pyloridis infection. Lancet 1986; i: 965-6.

17 Levi S, Beardshall K, Haddad G, Playford R, Ghosh P, Calam $J$. Campylobacter pylori and duodenal ulcers: the gastrin link. Lancet 1989; i: 1167-8.

18 Sarosiek J, Roche JK, Marshall B, McCallum RW. Urease enzyme inhibition by bismuth subsalicylate; a putative enzyme inhibition by bismuth subsalicylate; a putative

19 Yallow RS, Berson SA. Radioimmunoassay of gastrin. Gastroenterology 1970; 58: $1-14$.

20 El Nujumi AM, Dorrian CA, Chittajallu RS, Neithercut WD McColl KEL. Effect of inhibition of Helicobacter pylor urease activity by acetohydroxamic acid on serum gastrin in duodenal ulcer subjects. Gut 1991; 32: 866-70.

21 Cave DR, Vargas M. Effect of campylobacter pylori protein on acid secretion by parietal cells. Lancet 1989; ii: 187-9.

22 Graham DY, Alpert LC, Smith JL, Yoshimura HH. Iatrogenic Campylobacter pylori infection is a cause of epidemic achlorhydria. Am $\mathcal{F}$ Gastroenterol 1988; 83: 974-80.

23 Goodwin CS, Armstrong JA, Marshall BJ Campylobacter pyloridis, gastritis and peptic ulceration. $\mathcal{F}$ Clin Pathol 1986; 39: 353-65. 